\title{
Population fluctuations in the pink hibiscus mealybug and its natural enemies in Annona squamosa (Annonaceae) in Roraima, Brazil
}

\author{
Marcelo NEGRINI ${ }^{1 *}$, Elisangela G. F. MORAIS², Jéssica S. R. BATISTA³, Edvan A. CHAGAS² \\ 1 Universidade Federal de Roraima (UFRR), Programa de Pós-Graduação em Recursos Naturais (PRONAT), Av. Capitão Ene Garcez 2413, CEP 69304-000, Boa Vista, RR, \\ Brasil \\ 2 EMBRAPA Roraima, Pesquisa, Rodovia BR-174 Km 8, Distrito Industrial, CEP 69301 970, Boa Vista, RR, Brasil \\ 3 Instituto Federal de Roraima, Av. Glaycon de Paiva 2496, Pricumã, CEP 69303-340, Boa Vista, RR, Brasil \\ * Corresponding author: marcelo.nnegrini@gmail.com
}

\begin{abstract}
Maconellicoccus hirsutus (Hemiptera, Pseudococcidae), a species of economic interest, especially for fruit plants, is expanding on the South American continent. Information about the population dynamics of this pest associated with control by natural enemies and cultural practices is fundamental for its management. Our objective was to study the population fluctuations in M. hirsutus and its natural enemies in a sugar-apple (Annona squamosa) orchard in Roraima, northern Brazil. Trees were evaluated monthly over a 12 -month period. Infestation rates by $M$. hirsutus and its parasitism were also estimated for potential host plants around the study area. Highest infestation occurred in August and February-March. Alternative hosts were infested during the off-season, mainly fruit. Lacewings and the parasitoid Anagyrus kamali (Hymenoptera, Encyrtidae) were abundant natural enemies. Average parasitism by $A$. kamali in fruits was $50 \%$, with highest rates in periods of greatest infestation by $M$. hirsutus. Fruitification pruning reduced $M$. hirsutus populations.
\end{abstract}

KEYWORDS: Anagyrus kamali, biological control, Maconellicoccus hirsutus

\section{Flutuação populacional da cochonilha-rosada e seus inimigos naturais em Annona squamosa (Annonaceae) em Roraima, Brasil}

\section{RESUMO}

Maconellicoccus hirsutus (Hemiptera, Pseudococcidae), praga de inúmeras espécies, especialmente frutíferas, está se expandindo no continente sul-americano. Informaçóes sobre sua dinâmica, inimigos naturais e práticas culturais são importantes para seu manejo. Nosso objetivo foi estudar as flutuaçóes da população em $M$. hirsutus e seus inimigos naturais em um pomar de ata (Annona squamosa) em Roraima, Brasil. As árvores foram avaliadas mensalmente ao longo de um período de 12 meses e as taxas de infestaçáo por $M$. hirsutus e parasitismo foram estimadas. A maior infestação ocorreu em agosto de 2014 e entre fevereiro e março de 2015. Hospedeiros alternativos foram infestados durante a entressafra da ata. Bicho-lixeiro e o parasitoide Anagyrus kamali (Hymenoptera, Encyrtidae) foram os inimigos naturais mais importantes. O parasitismo médio por $A$. kamali nos frutos foi de $50 \%$, com maiores taxas nos períodos de maior infestação por $M$. hirsutus. A poda de frutificaçáo reduziu as populaçóes de $M$. hirsutus.

PALAVRAS-CHAVE: Anagyrus kamali, controle biológico, Maconellicoccus hirsutus 
The pink hibiscus mealybug, Maconellicoccus hirsutus Green (Hemiptera, Pseudococcidae), native to South Asia (Williams 1996), is a serious pest that was introduced to the Americas in the 1990s (Sagarra and Peterkin 1999). In Brazil, $M$. hirsutus was detected in 2010 in the northern region, in Roraima state (Marsaro Júnior et al. 2013), in 2012 in the southwestern region, in Espírito Santo state (Culik et al. $2013 \mathrm{ab}$ ), and subsequently in the states of Bahia (CEPLAC/ CEPEC 2014) and Santa Catarina (Alexandre et al. 2014) in 2013, and Pernambuco (Oliveira et al. 2014), Alagoas (Broglio et al. 2015), São Paulo (Peronti et al. 2016) and Mato Grosso (Morais et al. 2015) in 2014.

Maconellicoccus hirsutus is polyphagous, causing high economic damage to fruits and trees (Rosas-García and Parra-Brancamonte 2011; CEPLAC/CEPEC 2014; Oliveira et al. 2014; Broglio et al. 2015; Chong et al. 2015), and attacks practically all host plant structures, but preferably seedlings and young stems, flowers and fruits (Vitullo et al. 2009). It sucks sap, and its toxic saliva causes shortening of internodes, curling and crinkling of leaves, and deformation and early fall of fruits and flowers. Indirect damage is caused by development of sooty mold, a fungus that covers plant structures, and its waxy layer preventing fruit and ornamental plant trade (Nardo and Tambasco 1998; Kairo et al. 2000).

Fluctuations in pest populations in perennial crops are often correlated to climatic conditions, the productive period of the crop and associated natural enemies (Chagas et al. 1982; Garcia and Corseuil 1998; Arioli et al. 2005). Therefore, our aim was to study the annual population fluctuations in M. hirsutus on cultivated sugar-apple, Annona squamosa L. (Annonaceae) in association with resource availability and the mealybug's natural enemies.

The study was conducted in a sugar-apple (Annona squamosa L.) orchard of approximately 1.5 hectares in the municipality of Cantá, Roraima state, Brazil (243’5 'N, 603'14”W, 74 masl). The climate is tropical, with a dry season in winter (AW type, Koppen classification), and average annual rainfall of $1,420 \mathrm{~mm}$, with a rainy season from May to August (INMET 2015). Until 2014, the trees were not pruned, and infestation by $M$. hirsutus was high on fruits. From 2014 onwards two annual fructification pruning's followed by spraying with a bordeaux mixture and mineral oil were conducted, except in the evaluated trees. In the trees with high population density of $M$. hirsutus, the pruning and phytosanitary treatments were conducted only in February 2014.

Data were collected monthly from April 2014 to March 2015. A row of 20 sugar-apple trees was monitored by, counting the number of $M$. hirsutus and their natural enemies on four organs (branch, bud, flower and fruit). Nine units of each organ were assessed per tree, three in each basal, middle and apical position. We also evaluated possible hosts in a 200$\mathrm{m}$ radius around the orchard belonging to Mangifera indica $\mathrm{L}$.
(Anacardiaceae), Averrhoa carambola L. (Oxalidaceae), Annona muricata (Annonaceae), Xylopia aromatica (Lam.) Mart. (Annonaceae), Cocos nucifera L. (Arecaceae) and Gossypium sp. (Malvaceae).

Mealybug infestation was measured using a scale (Suresh and Chandra 2008) based on 0 (null), 1-10 (low), 11-20 (medium) and $>20$ (high) individuals per shoot. Infested fruits of $A$. muricata and $A$. carambola were collected to assess parasitism rates in the laboratory by counting the total number and number of parasitized mummies of $M$. hirsutus. Each fruit was individually placed into a transparent plastic container covered with anti-aphid screen until emergence of parasitoid adults. Emerged parasitoids were removed and counted (males and females) every three days, until the $18^{\text {th }}$ day, and females and placed in $70 \%$ ethanol for identification. The population density of $M$. hirsutus was compared between first (pruned) and second (not pruned) harvest by means of a t-test.

Numbers of adults, nymphs and ovisacs of $M$. hirsutus per sugar-apple fruit were highest in August of 2014 and FebruaryMarch of 2015 (Figure 1A). Pruning in February 2014 kept the area free of infestation until July, while the absence of pruning for the second harvest (January-February) allowed adult, ovisac and nymph numbers to increase significantly ( $\mathrm{p}$ $=0.006$ ) (Figure 1A). $99.5 \%$ of the infestation by $M$. hirsutus was on fruits, and $0.5 \%$ on buds. The average of infested fruit was only $5.2 \%$ and the highest infestation rates occurred in September $2014(11,1 \%)$ and February 2015 (13,2\%) (Figure 1B). Only $17.1 \%$ fruits had high infestation level, $14.3 \%$ medium and $68.6 \%$ low. Maconellicoccus hirsutus was also found on A. carambola and A. muricata fruits during the vegetative period of $A$. squamosa.

The natural enemies of $M$. hirsutus observed in the sugarapple orchard were the parasitoid Anagyrus kamali Mourse (Hymenoptera, Encyrtidae) and lacewing eggs (Neuroptera, Chrysopidae). Mean oviposition mass of lacewings was 33.75 eggs. Parasitism rates were higher in the months of greatest infestation by $M$. hirsutus (Figure 1). Parasitized mummies were an average $19.2 \%$ in the field, and $55.1 \%(15.1-78.8 \%$, in the laboratory. Anagyrus kamali also parasitized M. hirsutus infesting A. carambola and A. muricata fruits ( $48.3 \%$ and $39.7 \%$, respectively) (Table 1 ).

Table 1. Parasitism rate, mean number of mummies parasitized per fruit and mean number of parasitoid individuals of Anagyrus kamali (Hymenoptera, Encyrtidae) that emerged from sugar-apple, starfruit and soursop fruits.

\begin{tabular}{lccc}
\hline Culture (fruit) & $\begin{array}{c}\text { Parasitism } \\
\text { rate (\%) }\end{array}$ & $\begin{array}{c}\text { N parasitized } \\
\text { mummies }\end{array}$ & N parasitoids \\
\hline Annona squamosa & 55.1 & 26.1 & 32.7 \\
Annona muricata & 48.3 & 388.6 & 165.7 \\
Averrhoa carambola & 39.7 & 142.0 & 70.5 \\
Average & $49.7 \pm 3.2$ & $142.9 \pm 65.4$ & $70.5 \pm 23.1$ \\
\hline
\end{tabular}




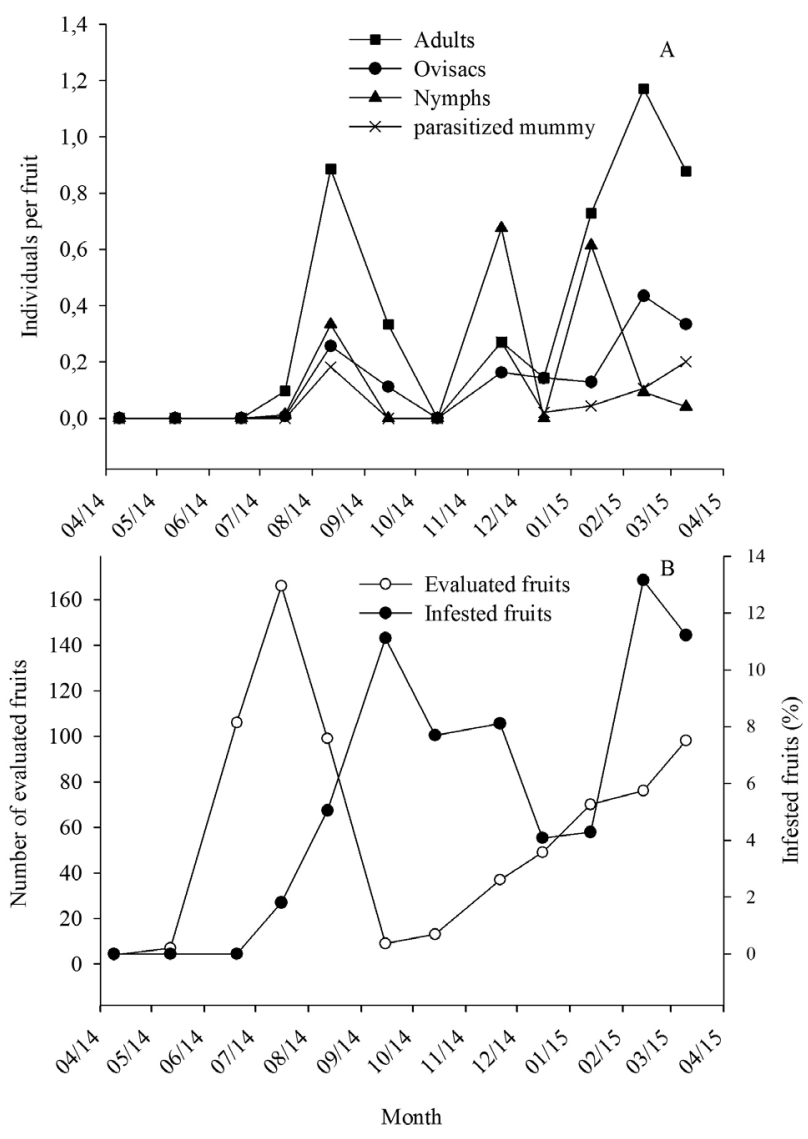

Figure 1. A. Population dynamics of adults, nymphs and ovisacs of Maconellicoccus hirsutus (Hemiptera, Pseudococcidae) and of parasitized mummies per fruit throughout the yearly cycle and; B. Number of evaluated and infested (5) fruits throughout the yearly cycle.

The population peaks of $M$. hirsutus coincided with the fructification of sugar-apples. Pruning unharvested fruits and infested branches is standard in fruit production and induces flowering and fruiting (Paiva and Fioravanço 1994) and is also important for pest management. Pruning and burning infested material followed by insecticide application are recommended for the management of M. hirsutus (Sagarra and Peterkin 1999).

The preferential infestation of sugar-apple fruits by $M$. hirsutus may be related to their nutritional quality and syncarpous structure, which provides protection for the mealybugs. The presence of $M$. hirsutus on other fruit species only during the harvest period of sugar-apples confirms its preference for the latter host (Culik et al. 2013a,b). The low infestation rate of fruit was likely related to biological control by $A$. kamali. This parasitoid was likely introduced with $M$. hirsutus in Brazil (Marsaro Júnior et al. 2013) and Colombia (Evans et al. 2012; Rodríguez 2012), and has high specificity to M. hirsutus (Sagarra et al. 2001) with high efficiency in its biological control (Michaud and Evans 2000; Roltsch et al. 2006; Garcia-Valente et al. 2009; Reddy et al. 2009; IsiordiaAquino et al. 2012).

Biological control with the parasitoid Anagyrus kamali and crop management, mainly fructification pruning, are effective strategies for reducing the population levels of $M$. hirsutus. Monitoring and control in adjacent plants should be part of integrated management strategies.

\section{ACKNOWLEDGEMENTS}

To Embrapa Roraima and Conselho Nacional de Desenvolvimento Científico e Tecnológico (CNPq) for financial support. MN received a scholarship from Coordenação de Aperfeiçoamento de Pessoal de Nível Superior (CAPES).

\section{REFERENCES}

Alexandre, F.; Souza, G.P.; Ebel, J.; Vieira, R.D.A.; Krueger, R. 2014. Levantamento de detecção da praga Maconellicoccus hirsutus Green (cochonilha rosada do hibisco), em cultivos urbanos de hibiscos e ornamentais em Santa Catarina. (http://www.vendasc.com.br/downloads/ anais_V_conferencia.pdf). Accessed on 02/05/2016.

Arioli, C.J.; Carvalho, G.A.; Botton, M. 2005. Flutuação populacional de Grapholita molesta (Busck) com armadilhas de feromônio sexual na cultura do pessegueiro em Bento Gonçalves, RS, Brasil. Ciência Rural, 35: 1-5.

Broglio, S.M.F.; Cordero, E.P.; Santos, J.M.; Micheletti, L.B. 2015. Registro da cochonilha-rosada-do-hibisco infestando frutíferas em Maceió, Alagoas, Brasil. Revista Caatinga, 28: 242 - 248.

CEPLAC/CEPEC. 2014. Ocorrência da cochonilha rosada (Maconellicoccus hirsutus, Green) em cacauais da Bahia e Espírito Santo. Comissáo Executiva do Plano da Lavoura Cacaueira/ Centro de Pesquisas do Cacau-CEPEC, 1: 1 (http://www. ceplac.gov.br/restrito/lerNoticia.asp?id=2159). Accessed on 15/11/2015.

Chagas E.F.; Neto, S.S.; Braz, A. J.B.P.; Mateus, C.P.B.; Coelho, I.P. 1982. Flutuaçáo populacional de pragas e predadores em citros. Pesquisa Brasileira Agropecuária, 17: 817-824.

Chong, J.H.; Aristízabal, L.F.; Arthurs, S.P. 2015. Biology and management of Maconellicoccus hirsutus (Hemiptera: Pseudococcidae) on ornamental plants. Journal of Integrated Pest Management, 6: 1-14.

Culik, M.P.; Fornazier, M.J.; Martins, D.S.; Zanuncio Junior, J.S.; Ventura, J.A.; Peronti, A.L.B.G.; Zanuncio, J.C. 2013a. The invasive hibiscus mealybug Maconellicoccus hirsutus (Hemiptera: Pseudococcidae) and its recent range expansion in Brazil. Florida Entomologist, 96: 638-640.

Culik, M.P.; Fornazier, M.J.; Martins, D.S.; Zanuncio Junior, J.S.; Ventura, J.A.; Peronti, A.L.B.G.; Zanuncio, J.C. 2013b. The invasive mealybug Maconellicoccus hirsutus: lessons for its current range expansion in South America and invasive pest management in general. Journal of Pest Science, 86: 387-398.

Evans, G.; Kondo, T.; Maya-Álvarez, M.F.; Hoyos-Carvajal, L.M.; Quiroz, J.A.; Silva-Gómez, M. 2012. First report of Anagyrus 
kamali Moursi and Gyranusoidea indica Shafee, Alam and Agarwal (Hymenoptera: Encyrtidae), parasitoids of the pink hibiscus mealybug Maconellicoccus hirsutus (Green) (Hemiptera: Pseudococcidae), on San Andres Island, Colombia. Corporación Colombiana de Investigación Agropecuaria, 13: 219-222.

Garcia, F.R.M.; Corseiul E. 1998. Flutuação populacional de Anastrepha fraterculus

(Wiedemann) e Ceratitis capitata (Wiedemann) (Diptera, Tephritidae) em pomares de pessegueiro em Porto Alegre, Rio Grande do Sul. Revista Brasileira de Zoologia, 15: 153-158.

INMET INSTITUTO NACIONAL DE METEOROLOGIA (INMET). Normais Climatológicas. (http://www.inmet.gov. $\mathrm{br} /$ portal/index.php?r=clima/normaisClimatologicas) Accessed on $05 / 10 / 2017$.

Isiordia-Aquino, N.; Robles - Bermúdez, A.; Gracía - Martínez, O.; Lomelí - Flores, R.; Gómez - Aguilar, J.R.; Espino - Alvarez, R. 2012. Especies forestales y arbustivas asociadas a Maconellicoccus hirsutus (Green) (Hemiptera: Pseudococcidae) en el norte de Nayarit, Mexico. Acta Zoológica Mexicana, 28: 414-426.

Kairo, M.T.K.; Pollard, G.V.; Peterkin, D.D.; Lopez, V.F. 2000. Biological control of the hibiscus mealybug, Maconellicoccus hirsutus Green (Hemiptera: Pseudococcidae) in the Caribbean. Integrated Pest Management Reviews, 5: 241-254.

Marsaro Júnior, A.; Peronti, A.L.B.G.; Penteado-Dias, A.M.; Morais, E. G. F. 2013. First report of Maconellicoccus hirsutus (Green, 1908) (Hemiptera: Coccoidea: Pseudococcidae) and the associated parasitoid Anagyrus kamali Moursi, 1948 (Hymenoptera: Encyrtidae), in Brazil. Brazilian Journal of Biology, 73: 413-418.

Michaud, J.P.; Evans, G.A. 2000. Current status of pink hibiscus mealybug in Puerto Rico including a key to parasitoid species. Florida Entomolologist, 83: 97-101.

Morais, E.G.F.; Peronti, A.L.B.G.; Marsaro Júnior, A.L.; Amaro, G.C. 2015. Cochonilha-rosada, Maconellicoccus hirsutus (Green). In: Vilela, E. F.; Zucchi, R. A. (Eds.). Pragas introduzidas no Brasil: insetos e ácaros. FEALQ, Piracicaba, p. 328-344.

Nardo, E.A.B.; Tambasco, F. J. 1998. O Brasil se prepara para receber (Maconellicoccus hirsutus (Green) (Hemiptera: Pseudococcidae). Informativo da Sociedade Entomológica do Brasil, 23: 1-5.

Oliveira, J.E.M.; Lopes, F.S.C.; Oliveira, M.D.; Pereira, V.S.; Freitas, M.T.S.; Oliveira, J.V.; Aquino, V.B. 2014. Registro de ocorrência da cochonilha-rosada Maconellicoccus hirsutus no Semiárido Brasileiro. In Proceedings of XXV Congresso Brasileiro de Entomologia, Goiania, Goiás, 14-18 Sept 2014.
Peronti, A.L.B.G.; Martinelli, N, M.; Alexandrino, J.G.; Marsaro Júnior, A.L.; Penteado-Dias, A.M.; Almeida, L.M. 2016. Natural enemies associated with Maconellicoccus hirsutus (Hemiptera: Pseudococcidae) in the State of São Paulo, Brazil. Florida Entomologist, 99: 21-25.

Reddy, C.V.P.; Muniappan, R.; Cruz, Z.T.; Naz, F.; Bamba, J.P.; Tenorio, J. 2009. Present status of Maconellicoccus hirsutus (Hemiptera: Pseudococcidae) in the Mariana Islands and its control by two fortuitously introduced natural enemies. Journal of Economic Entomology, 102: 1431-1439.

Rodríguez, J.M.M. 2012. Primer registro de parasitoides de la cochinilla rosada del hibisco, Maconellicoccus hirsutus (Hemiptera: Pseudococcidae), em Colombia. Revista Colombiana de Entomología, 38: 274-275.

Roltsch, W.J.; Meyerdirk, D.E.; Warkentin, R.; Andress, E.R.; Carrera, K. 2006. Classical biological control of the pink hibiscus mealybug, Maconellicoccus hirsutus (Green), in southern California. Biological Control, 37: 155-166.

Rosas-García, N.M.; Parra-Brancamonte, G.M. 2011. Incidencia de la cochinilla rosada del hibisco em cultivares de mango de Nayarit, México. Acta Zoológica Mexicana, 27: 407-418.

Sagarra, L.D.; Peterkin, D.D. 1999. Invasion of the Carribean by the hibiscus mealybug, Maconellicoccus hirsutus Green (Homoptera: Pseudococcidae). Phytoprotection, 80: 103-113.

Sagarra, L.D.; Vincent, C.; Stewart, R.K. 2001 Suitability of nine mealybug species (Homoptera: Pseudococcidae) as hosts for the parasitoid Anagyrus kamali (Hymenoptera: Encyrtidae). Florida Entomologist, 84: 112-116.

Suresh, S.; Chandra, K.P.2008. Seasonal incidence of economically importance coccid pests in Tamil Nadu, In: Branco M.; Franco J. C.; Hodgson, C. J. (Ed.). Proceedings of the XI International Symposium on Scale Insect Studies. Portugal: Oeiras, p. 285-291.

Vitullo, J.; Zhang, A.; Mannion, C.; Bergh, C. 2009. Expression of feeding symptoms from Pink Hibiscus Mealybug (Hemiptera: Pseudococcidae) by commercially important cultivars of hibiscus. Florida Entomologist, 92: 248-254.

Williams, D.J. 1996. A brief account of the hibiscus mealybug Maconellicoccus hirsutus (Hemiptera: Pseudococcidae), a pest of agriculture and horticulture, with descriptions of two related species from southern Asia. Bulletin of Entomological Research, 86: 617-628.

RECEIVED: 09/04/2017

ACCEPTED: 06/10/2017

ASSOCIATE EDITOR: Pitágoras da Conceição Bispo 